\title{
The comparisons of layers and the effect of additional firings on flexural strength and translucency of $5 \mathrm{Y}$-ZP
}

\author{
Hyung-Joon Kim, Soo-Yeon Shin* \\ Department of Prosthodontics, College of Dentistry, Dankook University, Cheonan, Republic of Korea
}

\begin{abstract}
Purpose: The purpose of this in vitro study was to investigate the flexural strength and translucency of three layers in 5Y-ZP and to assess the effect of additional firings on these properties. Materials and Methods: Sintered zirconia blocks were sectioned according to three layers : incisal, transition, and body. Disc-shaped specimens were fabricated from each layer. The diameter of specimens was $15.0 \mathrm{~mm}$ and each thickness of specimens for biaxial flexural strength test and translucency was $1.2 \mathrm{~mm}$ and $1.0 \mathrm{~mm}$. The specimens were classified into subgroups according to the number of firing $(0,1$, and 3 times; $n=10 /$ subgroup) and the additional firings were performed under $900^{\circ} \mathrm{C}$ using a furnace. Biaxial flexural strength and translucency was measured using universal testing machine and uv-vis spectrophotometer. X-ray diffraction (XRD) analysis was used for measurement of the phase identification. Oneway ANOVA, Tukey HSD test were performed $(\alpha=0.05)$. Results: There was no significant difference in flexural strength between the three layers $(P>0.05)$, while there was significant difference in translucency between different layers $(P<0.05)$. The flexural strength of incisal and transition layer was decreased by the single additional firing, and the three additional firings significantly decreased the flexural strength of three layers. The translucency of layer was decreased by additional firings except the body layer. The XRD patterns of all groups were similar. Conclusion: Three layers of 5Y-ZP were different only in translucency. Additional firings affected the flexural strength and translucency differently depending on the layers but crystalline phases were not changed. (J Dent Rehabil Appl Sci 2021;37(3):111-22)
\end{abstract}

Key words: monolithic zirconia; cubic phase; flexural strength; translucency; 5Y-ZP

\section{Introduction}

Metal-ceramic, glass-ceramic, and zirconia restorations have been used in dentistry for esthetic outcomes. Metal-ceramic materials have shown successful mechanical properties, however, they have esthetic limitations such as exposure to metal and gingival discoloration. ${ }^{1}$ Glass-ceramic materials show high translucency and advantages in esthetics, but those are vulnerable to fracture due to weak mechanical properties. ${ }^{2,3}$ Zirconia has good mechanical

*Correspondence to: Soo-Yeon Shin

Professor, Department of Prosthodontics, College of Dentistry, Dankook University, Dandae-ro 119, Dongnam-gu, Cheonan, Choongnam, 31116, Republic of Korea

Tel: +82-41-550-0256, Fax: +82-41-550-1975, E-mail: syshin@dankook.ac.kr

Received: June 21, 2021/Last Revision: July 13, 2021/Accepted: July 20, 2021 properties and biocompatibility, ${ }^{4}$ however, because of its intrinsic opacity, it is usually used with porcelain veneers. The major complication of zirconiaframework restorations is the high failure rate associated with porcelain chipping and fracture. ${ }^{5,6}$

Monolithic zirconia has been used to prevent porcelain chipping and fracture. ${ }^{7-9}$ Zirconia is a polymorphic material with three crystalline phases: monoclinic, tetragonal, and cubic. Pure zirconia is stable in monoclinic phase at room temperature and transforms into tetragonal phase at $1170^{\circ} \mathrm{C}$. Further,

Copyright@ 2021 The Korean Academy of Stomatognathic Function and Occlusion. (c) It is identical to Creative Commons Non-Commercial License. 
at $2370^{\circ} \mathrm{C}$, the cubic phase is stable. As zirconia cools down to room temperature, the transformation from tetragonal to monoclinic ( $\mathrm{t}-\mathrm{m}$ transformation) occurs with volume expansion inducing crack formation. The addition of stabilizer is essential to prevent the cracks. In dentistry, $3 \mathrm{~mol} \%$ yttria-stabilized tetragonal zirconia polycrystal (3Y-TZP) is most widely used. The metastable tetragonal phase at room temperature is facilitated by doping $3 \mathrm{~mol} \%$ yttria as stabilizer. The 3Y-TZP exhibits a special mechanism known as transformation toughening. The stress induces $\mathrm{t}-\mathrm{m}$ transformation and the volume expansion generates the compressive stress which resists crack propagation. Based on the mechanism, 3Y-TZP has an approximate flexural strength of 900 to $1200 \mathrm{MPa}$ and a fracture toughness of 9 to $10 \mathrm{MPa} / \mathrm{m}^{2}$. In the aspect of mechanical properties, monolithic zirconia is useful under defective interocclusal clearance or when less invasive preparation is needed. ${ }^{10,11}$ However, it is usually restricted to posterior teeth because of low translucency. ${ }^{12}$

Recently, to overcome the esthetic limitation, the translucency of zirconia was improved by increasing the yttria content. Doping zirconia with $5 \mathrm{~mol} \%$ yttria creates a partially stabilized zirconia containing approximately $50 \%$ cubic phase. ${ }^{13}$ The cubic phase of zirconia has isotropic refractive index, which decreases the light scattering and the birefringence phenomenon, ${ }^{11,14}$ while the tetragonal phase of zirconia has anisotropic refractive index. As a result, the $5 \mathrm{~mol} \%$ yttria-stabilized zirconia polycrystal (5Y-ZP) shows higher translucency compare to the conventional $3 \mathrm{Y}-\mathrm{TZP} .{ }^{14}$ Despite the improved translucency, the mechanical properties of $5 \mathrm{Y}-\mathrm{ZP}$ are lower than those of 3Y-TZP due to lack of transformation toughening. Thus, $5 \mathrm{Y}-\mathrm{ZP}$ is susceptible to damage because the stabilized cubic phase does not transform at room temperature. ${ }^{13-15}$

Many 5Y-ZP blocks, which are also known as translucent zirconia, are available commercially. According to the manufacturers' report, the flexural strength of 5Y-ZP blocks is approximately 600 to $750 \mathrm{MPa}$ and the translucency of 5Y-ZP blocks is improved. Furthermore, some of the 5Y-ZP blocks contain a pre-shaded multi-layers to reproduce the shades of natural teeth. ${ }^{16}$

Many studies report the mechanical properties and the translucency of 3Y-TZP ${ }^{3,4,17-20}$; however, studies related to the mechanical properties and translucency of $5 \mathrm{Y}-\mathrm{ZP}$ are lacking. If the mechanical properties and the translucency of layers are different, those of fixed prosthesis will depends on how the position of prosthesis in the 5Y-ZP block is determined by computer-aided design. The design of prosthesis should be different considering the clinical situations such as the natural shade of teeth, occlusion and interocclusal clearance. It is important to find out the difference of layers in 5Y-ZP but few studies have compared flexural strength and translucency between layers of $5 \mathrm{Y}-\mathrm{ZP}^{21,22}$ Despite the shade of $5 \mathrm{Y}-\mathrm{ZP}$ matches the classical shade guide, additional external staining is essential because the shade of natural teeth is variable. The manufacturers recommend firing under $900^{\circ} \mathrm{C}$, but the effect of additional firing on 5Y-ZP is unclear. This study aimed to investigate the biaxial flexural strength and translucency of different layers in 5Y-ZP and to assess the effect of additional firing on the flexural strength and translucency. The null hypotheses are (1) that there is no difference in the flexural strength and translucency of the different layers in 5Y-ZP and (2) that additional firing does not affect the flexural strength and translucency.

\section{Materials and Methods}

\section{Specimen preparation}

5Y-ZP block (Lava ${ }^{\text {TM }}$ Esthetic Fluorescent FullContour Zirconia, 3M ESPE, Seefeld, Germany) containing a pre-shaded multi-layer, was selected. Blocks of pre-sintered zirconia were sintered according to sintering protocols summarized in Table 1. After sintering, the blocks were sectioned according to three different layers: incisal, transition, and body layer. Disc-shaped specimens measuring $15.0 \mathrm{~mm}$ in diameter were cut from each layer using a surface grinding machine (HRG-150, AM Technology, Asan, Korea) and mirror-polished with diamond particles measuring up to $1.0 \mu \mathrm{m}$ using a grinding machine 
Table 1. Sintering protocol

\begin{tabular}{ccccc}
\hline & High temperature & Hold time & Rate of temperature increase & Rate of temperature decrease \\
\hline \multirow{2}{*}{ Lava $^{\mathrm{TM}}$ Esthetic } & $1,500^{\circ} \mathrm{C}$ & 120 minutes & $20^{\circ} \mathrm{C} / \mathrm{min}$ to $800^{\circ} \mathrm{C}$ & $-15^{\circ} \mathrm{C} / \mathrm{min}$ to $800^{\circ} \mathrm{C}$ \\
& & $10^{\circ} \mathrm{C} / \mathrm{min}$ to $1,500^{\circ} \mathrm{C}$ & $-20^{\circ} \mathrm{C} / \mathrm{min}$ to $250^{\circ} \mathrm{C}$ \\
\hline
\end{tabular}

A

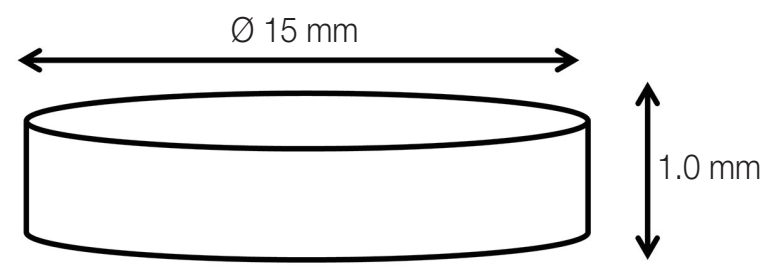

B

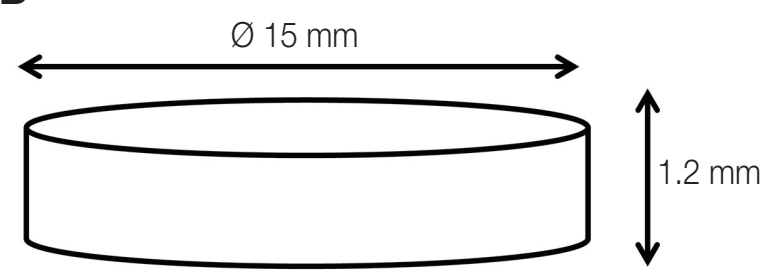

Fig. 1. The disc-shaped specimens. (A) Translucency test, (B) Biaxial flexural strength test.

(SPL-15 Grind X, OKAMOTO Co., Tokyo, Japan) to generate thicknesses of $1.0 \mathrm{~mm}$ in the translucency test and $1.2 \mathrm{~mm}$ in the biaxial flexural strength test (Fig. 1). The final dimensions of the specimens were measured with a digital caliper. The specimens were cleaned in distilled water for 10 min using ultrasonic cleaner (SD-120H, Mujigae Co, Seoul, Korea) and air-dried for $20 \mathrm{~s}$. The specimens of each layer for biaxial flexural strength test $(n=30)$ and for translucency test $(\mathrm{n}=30$ ) were randomly classified into three groups according to the number of additional firings: 0, 1, and 3 times. The classification is shown in Table 2 and each group comprised 10 specimens.

The additional firings were performed using a furnace (Programat ${ }^{\circledR}$ EP 5000, Ivoclar Vivadent, Schaan, Lichtenstein) to reproduce external staining. The firing schedule was set based on the manufacturer' s recommendation for low-temperature firing under $900^{\circ} \mathrm{C}$ (Table 3).

\section{Biaxial flexural strength test}

Disc specimens $(\varnothing=15.0 \mathrm{~mm}$, thickness $=1.2$ $\mathrm{mm}$ ) were fabricated according to ISO $6872: 2015 .^{23}$ The piston-on-three-ball test was used according to ASTM Standard F394-78. ${ }^{24}$ Three steel spheres $(\varnothing=$ $3.2 \mathrm{~mm}$ ) were positioned at $120^{\circ}$ from each other on the perimeter of a circle with $10.0 \mathrm{~mm}$ diameter. The circular cylinder of hardened steel with a $1.6 \mathrm{~mm}$ diameter was used for loading (Fig. 2). The biaxial flexural strength was measured using a universal testing

Table 2. Classification of groups of tested specimens

\begin{tabular}{ccccc}
\hline Layers & Group code & Firing $(\mathrm{n}=0)$ & Firing $(\mathrm{n}=1)$ & Firing $(\mathrm{n}=3)$ \\
\hline Incisal layer & IL & IL0 & IL1 & IL3 \\
Transition layer & TL & TL0 & TL1 & TL3 \\
Body layer & BL & BL0 & BL1 & BL3 \\
\hline
\end{tabular}

Table 3. Additional firing schedule

\begin{tabular}{ccccc}
\hline Dry-out time & Predrying temperature & Heat rate & High temperature & Cool time \\
\hline $5 \mathrm{~min}$ & $600^{\circ} \mathrm{C}$ & $50^{\circ} \mathrm{C} / \mathrm{min}$ & $850^{\circ} \mathrm{C}$ & $4 \mathrm{~min}$ \\
\hline
\end{tabular}




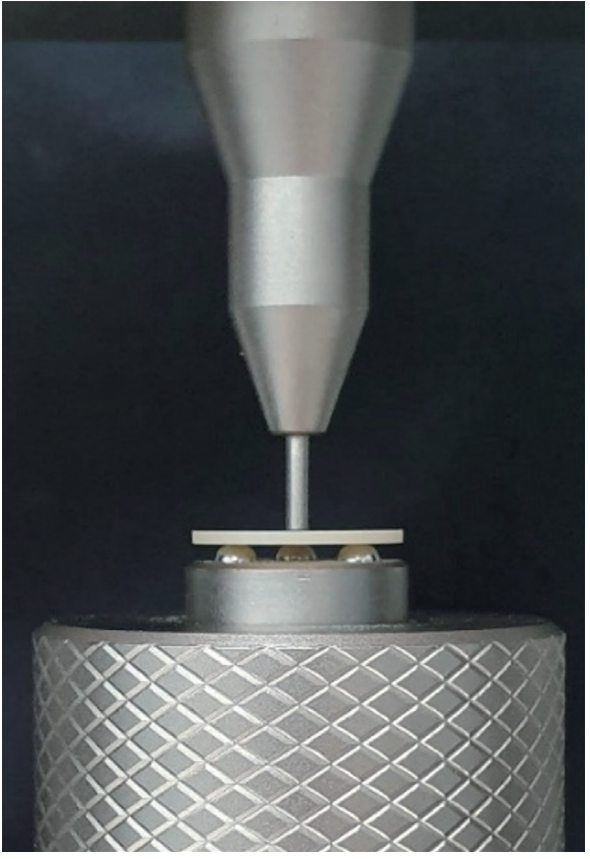

Fig. 2. The piston-on-three-ball test.

machine (QM100TS, QMESYS, Seoul, Korea) at a 1.0 $\mathrm{mm} / \mathrm{min}$ crosshead speed. The specimens were subjected to stress until fracture occurred and the load value causing fracture $(\mathrm{N})$ was recorded. The biaxial flexural strength was calculated using the following equation (1).

(1) $\mathrm{S}=-0.2387 \mathrm{P}(\mathrm{X}-\mathrm{Y}) / \mathrm{b}^{2}$

where: S; maximum center tensile stress $(\mathrm{MPa}), \mathrm{P}$; total load causing fracture $(\mathrm{N}), \mathrm{b}$; thickness of the specimen ( $\mathrm{mm}$ ). $\mathrm{X}$ and $\mathrm{Y}$ were determined using the following equation (2) and (3).

(2) $\mathrm{X}=(1+v) \ln \left(\frac{r_{2}}{r_{3}}\right)^{2}+\left[\frac{1-v}{2}\right]\left(\frac{r_{2}}{r_{3}}\right)^{2}$

(3) $\mathrm{Y}=(1+v)\left[1+\ln \left(\frac{r_{1}}{r_{3}}\right)^{2}\right]+(1-v)\left(\frac{r_{1}}{r_{3}}\right)^{2}$

where: $v$; Poisson's ratio, $r_{1}$; radius of the support circle $(\mathrm{mm}), r_{2}$; radius of the loaded area $(\mathrm{mm}), r_{3}$; radius of the specimen $(\mathrm{mm})$. In the present study, the parameters $v, r_{1}$, and $r_{2}$ were set to $0.33,5.0 \mathrm{~mm}$, and $0.8 \mathrm{~mm}$, respectively.

\section{Translucency}

Disc specimens $(\varnothing=15.0 \mathrm{~mm}$, thickness $=1.0$ $\mathrm{mm}$ ) were fabricated to measure the transmittance of light. A uv-vis spectrophotometer (UV-2600, SHIMADZU, Tokyo, Japan) with an integrating sphere was used to evaluate the total transmittance of light in percentage $\left(T_{t}\right)$ calculated using the following equation (4) and (5).
(4) $\mathrm{T}_{\mathrm{t}}=\frac{\mathrm{I}}{\mathrm{I}_{0}}$
(5) $\mathrm{T}_{\mathrm{t}} \%=\mathrm{T}_{\mathrm{t}} \times 100$

where: $\mathrm{T}_{t}$; total transmittance of light, $\mathrm{I}$; intensity of the light after its transmission through the specimen, $\mathrm{I}_{0}$; initial light intensity.

Measurement conditions were set as follows: wavelength range of 380 to $780 \mathrm{~nm}$, a data interval of 1 $\mathrm{nm}$, and a deuterium light source. The translucency was compared by selecting the mean $T_{t} \%$ values at the wavelength of $555 \mathrm{~nm}$. Since the eye is most sensitive to the wavelength of $555 \mathrm{~nm}$, the International Commission on Illumination (CIE S 017) and the Japanese industrial standard (JIS Z 8113) defined the wavelength of $555 \mathrm{~nm}$ as the maximum luminous intensity. ${ }^{25,26}$

\section{X-ray diffraction}

X-ray diffraction(XRD) analysis was used to evaluate the changes in phases after additional firing. The two specimens of each group were randomly selected and $\mathrm{Cu} \mathrm{K} \alpha(40 \mathrm{kV}, 40 \mathrm{~mA})$ XRD analysis was performed using a diffractometer (D8 ADVANCE; Billerica, Massachusetts, USA). Each specimen was analyzed from $20^{\circ}$ to $90^{\circ} 2 \theta$ with a step size of $0.02^{\circ}$.

\section{Statistical analysis}

The statistical analysis was conducted with IBM SPSS Statistics v24.0 (IBM Corp., Chicago, USA). The significance of the differences in flexural strength and translucency among the groups were analyzed by Kolmogorov-Smirnov Test, and one- 
way ANOVA. A post-hoc analysis was conducted via Tukey HSD test. The effect of additional firing on the flexural strength and translucency was analyzed using the same methods. The level of statistical significance was set at $5 \%$.

\section{Results}

Body layer showed the highest value and incisal layer showed the lowest value of biaxial flexural strength, but there was no significant difference among three layers $(P>0.05)$. Additional firing had significant effect on biaxial flexural strength of each layers. IL0 showed significantly higher flexural strength than IL1 $(P=0.033)$ and IL3 $(P=0.018)$, but there was no significant difference between IL1 and IL3 $(P>0.05)$. Among the transition layer groups, TL0 showed significantly higher flexural strength than TL1 $(P=$ $0.022)$ and TL3 $(P=0.004)$. However, no significant

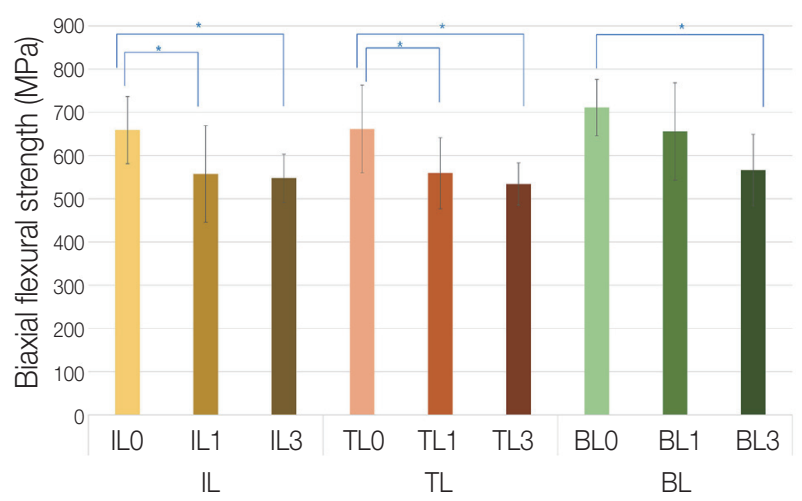

Fig. 3. Mean biaxial flexural strength.

* denotes significant difference at the level of 0.05 .

Table 4. Mean values and standard deviations of biaxial flexural strength $(\mathrm{MPa})$

\begin{tabular}{clll}
\hline & \multicolumn{3}{c}{ Mean (SD) } \\
Group & Firing $(\mathrm{n}=0)$ & Firing $(\mathrm{n}=1)$ & Firing $(\mathrm{n}=3)$ \\
\hline IL & $658.98(77.65)$ & $557.48(111.60)$ & $547.57(55.86)$ \\
TL & $661.62(101.31)$ & $559.21(82.23)$ & $534.17(49.11)$ \\
BL & $710.86(65.10)$ & $655.65(112.56)$ & $566.13(82.93)$ \\
\hline
\end{tabular}

SD: standard deviation, IL: Incisal laver, TL: Transition layer, BL: Body layer. difference between TL1 and TL3 was observed ( $P>$ 0.05, Fig. 3). BL0 showed the highest biaxial flexural strength but significant difference was detected only between BL0 and BL3 $(P=0.003)$.

Unlike the flexural strength, the translucency of three layers showed significant difference.

The incisal layer was significantly more translucent than other layers $(P<0.05)$ and the body layer was significantly less translucent than other layers $(P<$ 0.05 , Fig. 4, Table 5).

IL3 group was less translucent than ILO $(P<0.001)$ and IL1 $(P<0.001)$, but IL0 and IL1 showed no significant difference $(P>0.05)$. TL0 showed the highest value and TL3 showed the lowest value of transmittance among the transition layer groups $(P<$ 0.001). In contrast to other layers, there was no significant difference of transmittance after additional firings in body layer $(P>0.05)$.

The total transmittance of each layer from 380 to

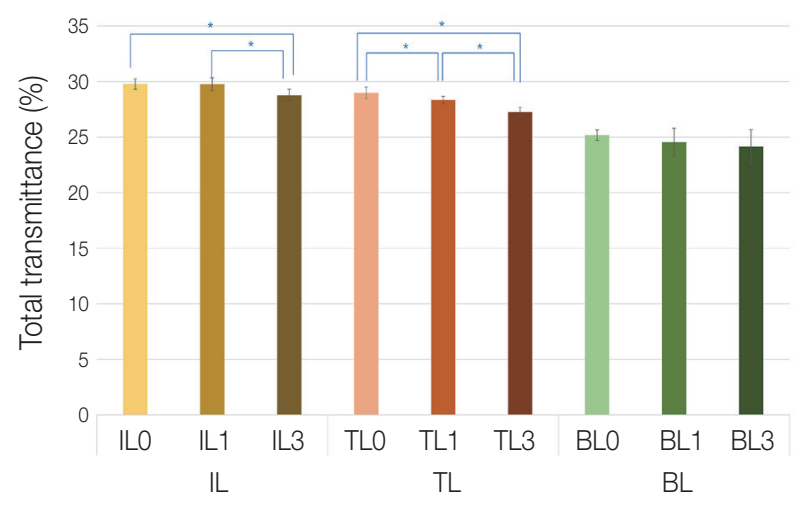

Fig. 4. Mean total transmittance of $555 \mathrm{~nm}$ wavelength. * denotes significant difference at the level of 0.05 .

Table 5. Mean values and standard deviations of total transmittance (\%) measured at $555 \mathrm{~nm}$ wavelength

\begin{tabular}{cccc}
\hline & \multicolumn{3}{c}{ Mean $(\mathrm{SD})$} \\
Group & Firing $(\mathrm{n}=0)$ & Firing $(\mathrm{n}=1)$ & Firing $(\mathrm{n}=3)$ \\
\hline IL & $29.76(0.47)$ & $29.74(0.58)$ & $28.77(0.53)$ \\
TL & $28.97(0.53)$ & $28.34(0.32)$ & $27.26(0.42)$ \\
BL & $25.17(0.47)$ & $24.55(1.24)$ & $24.14(1.53)$ \\
\hline
\end{tabular}

SD: standard deviation, IL: Incisal layer, TL: Transition layer, BL: Body layer. 
$780 \mathrm{~nm}$ wavelength was shown in Fig. 5. The total transmittance showed an upward tendency as the wavelength increased; however, all layers exhibited a similar steep decline from 480 to $490 \mathrm{~nm}, 500$ to 525 $\mathrm{nm}, 540$ to $543 \mathrm{~nm}$, and 637 to $655 \mathrm{~nm}$ wavelength.

The peak of the $x$-ray diffraction was observed in all groups around $30^{\circ}, 35^{\circ}, 50^{\circ}, 59^{\circ}, 62^{\circ}, 74^{\circ}, 81^{\circ}$, and $84^{\circ} 2 \theta$ showing similar patterns (Fig. 6). Definitive phase transformations were not observed after additional firings in all three layers.

\section{Discussion}

In this study, the differences in flexural strength and translucency between different layers of preshaded 5Y-ZP and the effect of additional firings on flexural strength and translucency of 5Y-ZP were tested. The flexural strength of different layers was similar, despite significant difference in translucency between different layers. Therefore, the first null hypothesis was partially rejected. The second null hypothesis that additional firing does not affect the flexural strength and translucency of 5Y-ZP was also rejected.

Biaxial flexural strength test does not show edge failure and the effect of crack direction is minimal, and therefore, is considered more accurate than uniaxial flexural strength. ${ }^{27,28}$ Thus, the flexural strength was measured using biaxial test and approximately 650 to $750 \mathrm{MPa}$ was measured in groups without additional firing. The result was similar to the flexural strength of another pre-shaded 5Y-ZP reported by Kwon et al. ${ }^{14}$ Although the 5Y-ZP showed a lower flexural strength than that of 3Y-TZP due to the lack of transformation toughening, it yielded higher flexural strength than lithium disilicate.

The disc-shaped specimens were fabricated after the sintering of $5 \mathrm{Y}-\mathrm{ZP}$ because the pre-sintered blocks were vulnerable, and the boundaries of three layers were difficult to distinguish completely before sintering due to ambiguous color differences. The unintentional stress may have occurred during fabrication of specimens but the result was in accordance with the flexural strength of other 5Y-ZP.

The layers of 3Y-TZP showed significantly different flexural strength, ${ }^{29}$ whereas the layers of $5 \mathrm{Y}-\mathrm{ZP}$ did not show significant differences despite the slight increase in flexural strength from the incisal layer to the body layer. It is difficult to explain the factors underlying the differences in results but the type and

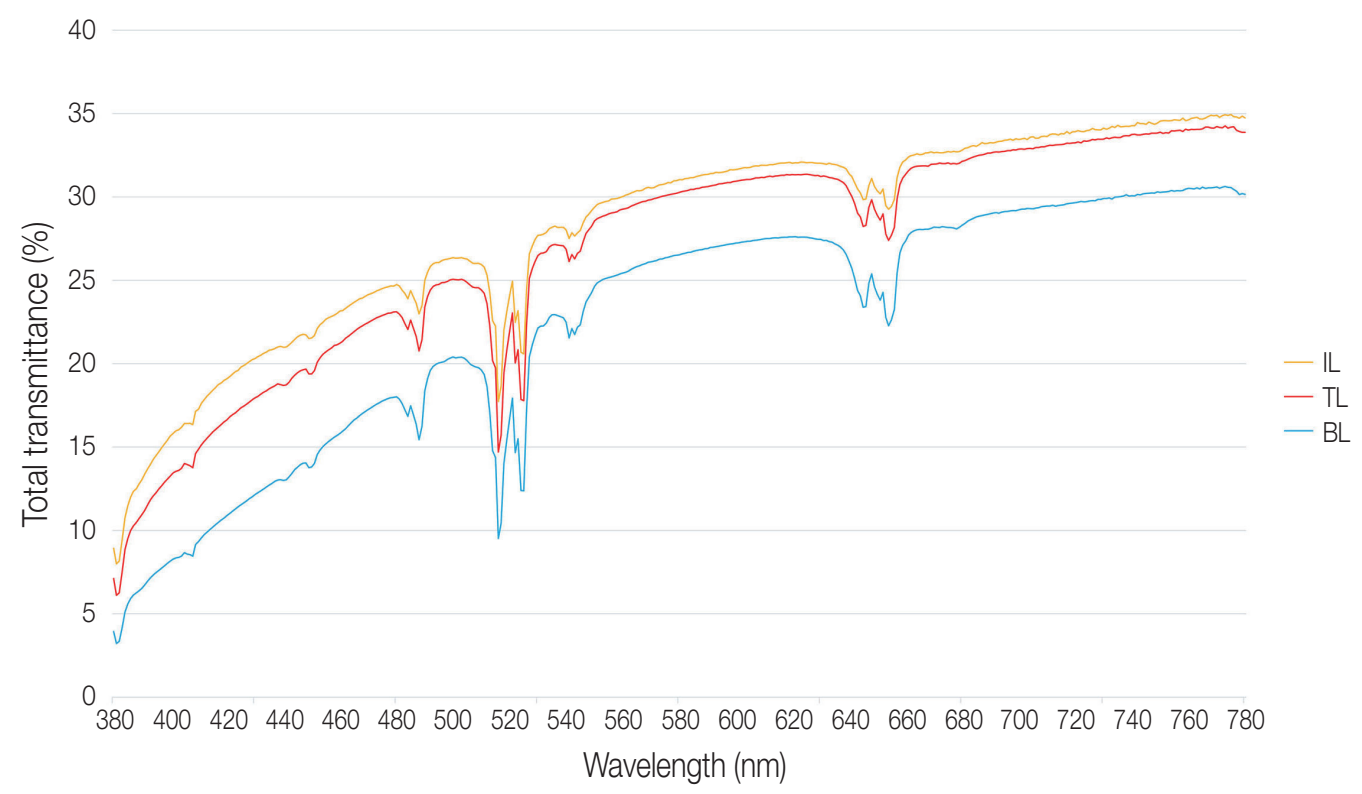

Fig. 5. Total transmittance spectrum for each layer. IL: Incisal layer, TL: Transition layer, BL: Body layer. 

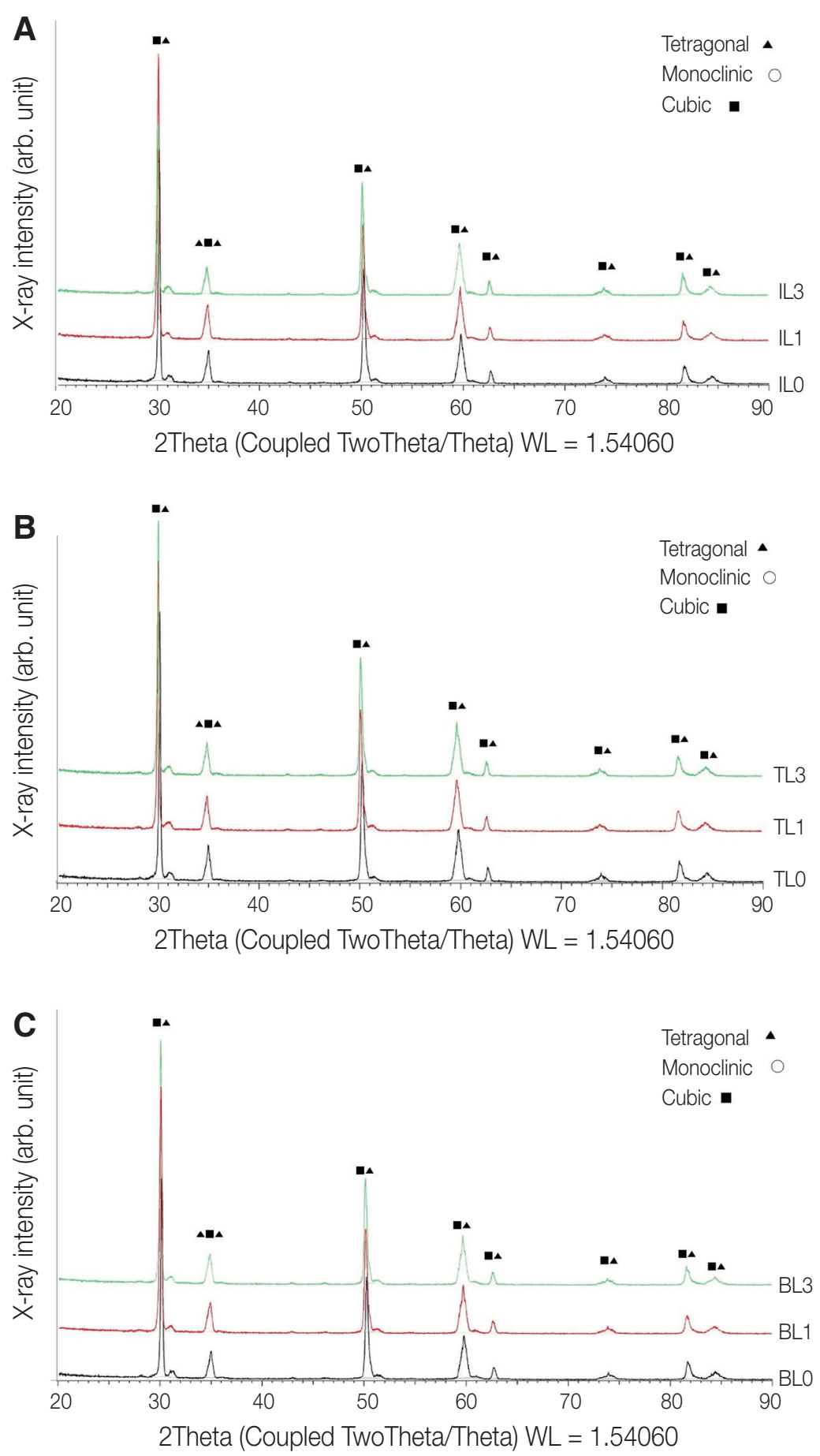

Fig. 6. Representative XRD patterns of 5Y-ZP. (A) Incisal layer groups, (B) Transition layer groups, (C) Body layer groups.

concentration of shading gradients may influence the strength of zirconia. ${ }^{20}$ Moreover, since the cubic phase is increased and lacks transformation toughening, the difference between layers might be minimal. The failure rates of fractures due to different flexural strength between layers may be reduced in 5Y-ZP.
Five veneering firing cycles did not affect the flexural strength of 3Y-TZP and the number of firing cycles had negligible effects on the flexural strength of $3 \mathrm{Y}-\mathrm{TZP} .^{30,31}$ In contrast, the additional firing decreased the flexural strength of 5Y-ZP. Three additional firings significantly decreased the flexural 
strength of the three layers and the single additional firing decreased the flexural strength of incisal and transition layers. The factors underlying the differential effects of additional firing on 5Y-ZP compared with that of 3Y-TZP are unclear; however, the microstructure of zirconia might influence the response of zirconia to the heat. The firing may also lead to changes in the shape of porosities and impurities embedded in the specimens, facilitating crack propagation and decrease in the flexural strength. ${ }^{32}$ The single additional firing decreased the flexural strength of $5 \mathrm{Y}-\mathrm{ZP}$ and the three firings resulted in a detrimental effect, and therefore, not recommended for staining. If the portion of the incisal and transition layer is increased, even the single additional firing should be done with consideration.

There are various methods to measure the translucency of materials: contrast ratio (CR), translucency parameter $(\mathrm{TP})$, direct transmittance $\left(\mathrm{T}_{\mathrm{d}} \%\right)$ and total transmittance $\left(T_{t} \%\right) .{ }^{33-36}$ The CR is a measure of the ratio of reflectance from a material on a black background to the reflectance on a white background. The TP refers to the color difference of material between black and white backgrounds. Measurement of $T_{t} \%$ is appropriate for transparent or clear materials because of minimal scatter or diffusion of light. Instead, when measuring the translucency of translucent or hazy materials such as dental ceramics, it is more appropriate to measure the TP because it indicates not only the direct transmittance but also diffuse transmittance. ${ }^{33,36,37}$ Also, the CR is not a direct method for measuring translucency and should not be used below 50\% transmission. ${ }^{38}$ Therefore, the $\mathrm{T}_{\mathrm{t}} \%$ was measured to evaluate the translucency.

The translucency of various 5Y-ZP was reported in current studies. ${ }^{39,40}$ In this study, the translucency of 5Y-ZP was lower than the results of other studies. In contrast to other pre-shaded 5Y-ZP which uses 2 or 3 shading gradients, the $5 \mathrm{Y}-\mathrm{ZP}$ used in this study consists of 4 shading gradients, which include the fluorescent shading element for representing the fluorescence of natural teeth. Increased number of shading gradients might decrease the translucency. Another possible explanation is that the result showed a lower translucency due to the average grain size. The manufacturer reports that the average grain size of Lava ${ }^{\mathrm{TM}}$ Esthetic Fluorescent Full-Contour Zirconia (3M ESPE) was $0.7 \mu \mathrm{m}$, while the average grain size of another $5 \mathrm{Y}-\mathrm{ZP}$ was $1.7 \mu \mathrm{m} .{ }^{40,41}$ The larger the grain size is, the more translucent the zirconia becomes due to decrease of grain boundaries. Since the 5Y-ZP in the present study had a smaller grain size, the light scatter might increase.

The translucency of different layers of $5 \mathrm{Y}-\mathrm{ZP}$ showed no significant difference in the previous studies, ${ }^{21,22}$ but the studies measured the TP to evaluate translucency. However, the translucency was significantly different between layers based on $\mathrm{T}_{t} \%$. When designing the restoration using CAD, the apicocoronal positioning of the restoration should be determined carefully because of varying translucency of layers and diverse shade of natural teeth. If the shade of abutment is similar to that of adjacent teeth, positioning the design of the restoration coronally in the 5Y-ZP block will produce better outcome by reproducing the shade of natural teeth. However, if the shade of abutment is different from that of adjacent teeth and masking is needed, the restoration should be positioned apically. The additional firing significantly decreased the translucency of 5Y-ZP except the body layer. Therefore, in the aspect of esthetic outcome, three additional firings of 5Y-ZP are not recommended and the single additional firing should be considered carefully.

The total transmittance of each layer was different but the spectral patterns were similar to each other. The transmittance increased as the wavelength increased, but there were steep declines at 480 to $490 \mathrm{~nm}, 500$ to $525 \mathrm{~nm}, 540$ to $543 \mathrm{~nm}$ and 637 to $655 \mathrm{~nm}$ wavelength, consistent with blue, green, red colors. The 3 colors are the complementary colors of cyan, magenta, yellow, which are the basic colors of subtractive mixture. Therefore, the pre-shaded $5 Y-Z P$ absorbed additional light at the specific wavelengths and decreased the translucency.

The three layers showed similar patterns of $x$-ray diffraction and the results were in accordance with the study of Inokoshi et al. ${ }^{41}$ In addition, the XRD patterns of groups fired additionally were not different from those before the additional firing. There 
was no change in the crystallographic phase of 5YZP after firing but the decrease of flexural strength and translucency occurred. Even though the phase transformation was not detected, the microstructure might be changed and the shading gradients might influence the 5Y-ZP due to additional firing.

The number of additional firings was set according to the study measuring the color change of porcelain after repeated staining procedures. The study reported that the color change was perceptible after the staining initially with one type of stain and the color change was perceptible after third staining in four stains. ${ }^{42}$ However, the limitation of this present study still remains that the gradual changes of flexural strength and translucency, which could appear in sequential increase in number of firings, could not be evaluated because the two additional firings were not carried out. A significant difference in translucency was found in incisal and transition layers between single additional firing and three such firings. The effect of sequential firings on $5 \mathrm{Y}-\mathrm{ZP}$ should be further studied for clinical use.

The additional firing was conducted without staining to evaluate the effect of low-temperature firing on flexural strength and translucency. The actual external staining might be detrimental because the low-firing temperature generates a porous glaze that wets the zirconia ${ }^{43}$ and the moisture results in grain faceting at the surface of zirconia. ${ }^{30}$ External staining might induce opacity of the 5Y-ZP as it absorbs the stain due to the microstructure and grain boundary. ${ }^{44}$ The light transmission may be decreased; however, further studies are needed to report the effect of external staining on translucency and flexural strength of $5 \mathrm{Y}-\mathrm{ZP}$, focusing on the change of microstructure and grain size of $5 \mathrm{Y}-\mathrm{ZP}$.

\section{Conclusion}

On the basis of this in vitro study, the following conclusions can be drawn:

- There was a difference only in translucency, not in flexural strength of three layers.

- Three additional firings significantly decreased the flexural strength of $5 \mathrm{Y}-\mathrm{ZP}$, and the flexural strength was decreased in incisal and transition layer by the single additional firing. The translucency of transition layer was decreased by the single additional firing and the translucency was decreased in incisal and transition layers by the three additional firings, while there was no significant difference following additional firing in the body layer.

- There was a significant difference in biaxial flexural strength and translucency after additional firing but no changes in crystalline phases were observed.

\section{Acknowledgments}

This study was financially supported by Department of Prosthodontics, College of Dentistry, Dankook University.

\section{ORCID}

Hyung-Joon Kim https://orcid.org/0000-0002-3162-7565

Soo-Yeon Shin https://orcid.org/0000-0001-6160-7277

\section{References}

1. Bagby M, Marshall SJ, Marshall GW Jr. Metal ceramic compatibility: a review of the literature. J Prosthet Dent 1990;63:21-5.

2. Isgrò G, Pallav P, van der Zel JM, Feilzer AJ. The influence of the veneering porcelain and different surface treatments on the biaxial flexural strength of a heat-pressed ceramic. J Prosthet Dent 2003;90:465-73.

3. Kim HK, Kim SH, Lee JB, Han JS, Yeo IS, Ha SR. Effect of the amount of thickness reduction on color and translucency of dental monolithic zirconia ceramics. J Adv Prosthodont 2016;8:37-42.

4. Christel P, Meunier A, Heller M, Torre JP, Peille $\mathrm{CN}$. Mechanical properties and short-term in-vivo evaluation of yttrium-oxide-partially-stabilized zirconia. J Biomed Mater Res 1989;23:45-61.

5. Teichmann M, Wienert AL, Rückbeil M, Weber V, Wolfart S, Edelhoff D. Ten-year survival and chipping rates and clinical quality grading of zirconia- 
based fixed dental prostheses. Clin Oral Investig 2018;22:2905-15.

6. Stefanescu C, Ionita C, Nechita V, Drafta S, Oancea L, Petre A. Survival Rates and Complications for Zirconia-Based Fixed Dental Prostheses in a Period up to 10 Years: A Systematic Review. Eur J Prosthodont Restor Dent 2018;26:54-61.

7. Christensen GJ. The all-ceramic restoration dilemma: where are we? J Am Dent Assoc 2011;142:66871.

8. Marchack BW, Sato S, Marchack CB, White SN. Complete and partial contour zirconia designs for crowns and fixed dental prostheses: a clinical report. J Prosthet Dent 2011;106:145-52.

9. Thalji GN, Cooper LF. Implant-supported fixed dental rehabilitation with monolithic zirconia: a clinical case report. J Esthet Restor Dent 2014;26:8896.

10. Malkondu O, Tinastepe N, Kazazoglu E. Influence of type of cement on the color and translucency of monolithic zirconia. J Prosthet Dent 2016;116:9028.

11. da Silva LH, de Lima E, de Paula Miranda RB, Favero SS, Lohbauer U, Cesar PF. Dental ceramics: a review of new materials and processing methods. Braz Oral Res 2017;31 Suppl 1:e58.

12. da Silva LH, de Lima E, Hochman M, Özcan M, Cesar PF. Monolithic Zirconia for Prosthetic Reconstructions : Advantages and Limitations. Curr Oral Health Rep 2017;4:197-200.

13. Zhang F, Inokoshi M, Batuk M, Hadermann J, Naert I, Van Meerbeek B, Vleugels J. Strength, toughness and aging stability of highly-translucent Y-TZP ceramics for dental restorations. Dent Mater 2016;32:e327-37.

14. Kwon SJ, Lawson NC, McLaren EE, Nejat AH, Burgess JO. Comparison of the mechanical properties of translucent zirconia and lithium disilicate. J Prosthet Dent 2018;120:132-7.

15. Zhang Y, Lawn BR. Novel Zirconia Materials in Dentistry. J Dent Res 2018;97:140-7.

16. Ueda K, Güth JF, Erdelt K, Stimmelmayr M, Kappert H, Beuer F. Light transmittance by a multi-coloured zirconia material. Dent Mater J 2015;34:3104.
17. Baldissara P, Llukacej A, Ciocca L, Valandro FL, Scotti R. Translucency of zirconia copings made with different CAD/CAM systems. J Prosthet Dent 2010;104:6-12.

18. Sato H, Yamada K, Pezzotti G, Nawa M, Ban S. Mechanical properties of dental zirconia ceramics changed with sandblasting and heat treatment. Dent Mater J 2008;27:408-14.

19. Zhang Y. Making yttria-stabilized tetragonal zirconia translucent. Dent Mater 2014;30:1195-203.

20. Nakamura K, Harada A, Ono M, Shibasaki H, Kanno T, Niwano Y, Adolfsson E, Milleding P, Örtengren U. Effect of low-temperature degradation on the mechanical and microstructural properties of tooth-colored 3Y-TZP ceramics. J Mech Behav Biomed Mater 2016;53:301-11.

21. Shamseddine L, Majzoub Z. Relative Translucency of a Multilayered Ultratranslucent Zirconia Material. J Contemp Dent Pract 2017;18:1099-106.

22. Kolakarnprasert N, Kaizer MR, Kim DK, Zhang Y. New multi-layered zirconias: Composition, microstructure and translucency. Dent Mater 2019;35:797806.

23. International Organization for Standardization. ISO 6872:2015 Dentistry - ceramic materials. Available from: https://www.iso.org/standard/59936. html (updated 2021 Sep 6).

24. ASTM International. ASTM F394-78 (1996), Test Method for Biaxial Flexure Strength (Modulus of Rupture) of Ceramic Substrates (Withdrawn 2001). West Conshohocken; PA; 1996.

25. International commission on illumination. CIE $\mathrm{S}$ 017-2011. International lighting vocabulary. Vienna, Austria:CIE. Available from: http://cie.co.at (updated 2015 Nov 16)

26. Japanese Standards Association. JIS Z 8113-1998. Lighting vocabulary. Tokyo, Japan: Japanese Standards Association. Available from: http://www.jsa. or.jp (updated 2015 Nov 16).

27. Seo DG, Roh BD. The comparison of relative reliability on biaxial and three point flexural strength testing methods of light curing composite resin. J Korean Acad Cons Dent 2006;31:58-65.

28. Anusavice KJ, Kakar K, Ferree N. Which mechanical and physical testing methods are relevant for 
predicting the clinical performance of ceramicbased dental prostheses? Clin Oral Implants Res 2007;18:218-31.

29. Wille S, Zumstrull P, Kaidas V, Jessen LK, Kern M. Low temperature degradation of single layers of multilayered zirconia in comparison to conventional unshaded zirconia: Phase transformation and flexural strength. J Mech Behav Biomed Mater 2018;77:171-5.

30. Xie H, Gu Y, Li Q, Qian M, Zhang F, Tay FR, Chen C. Effects of multiple firings on the low-temperature degradation of dental yttria-stabilized tetragonal zirconia. J Prosthet Dent 2016;115:495-500.

31. Nakamura K, Adolfsson E, Milleding P, Kanno T, Örtengren U. Influence of grain size and veneer firing process on the flexural strength of zirconia ceramics. Eur J Oral Sci 2012;120:249-54.

32. Chevalier J. What future for zirconia as a biomaterial? Biomaterials 2006;27:535-43.

33. Brodbelt RH, O'Brien WJ, Fan PL. Translucency of dental porcelains. J Dent Res 1980;59:70-5.

34. Johnston WM, Reisbick MH. Color and translucency changes during and after curing of esthetic restorative materials. Dent Mater 1997;13:89-97.

35. Wang F, Takahashi H, Iwasaki N. Translucency of dental ceramics with different thicknesses. J Prosthet Dent 2013;110:14-20.

36. Awad D, Stawarczyk B, Liebermann A, Ilie N. Translucency of esthetic dental restorative CAD/ CAM materials and composite resins with respect to thickness and surface roughness. J Prosthet Dent 2015;113:534-40.

37. Harada K, Raigrodski AJ, Chung KH, Flinn BD, Dogan S, Mancl LA. A comparative evaluation of the translucency of zirconias and lithium disilicate for monolithic restorations. J Prosthet Dent 2016; 116:257-63.

38. Spink LS, Rungruanganut P, Megremis S, Kelly JR. Comparison of an absolute and surrogate measure of relative translucency in dental ceramics. Dent Mater 2013;29:702-7.

39. Nassary Zadeh P, Lümkemann N, Sener B, Eichberger M, Stawarczyk B. Flexural strength, fracture toughness, and translucency of cubic/tetragonal zirconia materials. J Prosthet Dent 2018;120:948-54.
40. Camposilvan E, Leone R, Gremillard L, Sorrentino R, Zarone F, Ferrari M, Chevalier J. Aging resistance, mechanical properties and translucency of different yttria-stabilized zirconia ceramics for monolithic dental crown applications. Dent Mater 2018;34:879-90.

41. Inokoshi M, Shimizu H, Nozaki K, Takagaki T, Yoshihara K, Nagaoka N, Zhang F, Vleugels J, Van Meerbeek B, Minakuchi S. Crystallographic and morphological analysis of sandblasted highly translucent dental zirconia. Dent Mater 2018;34:508-18.

42. Cho MS, Lee YK, Lim BS, Lim YJ. Changes in optical properties of enamel porcelain after repeated external staining. J Prosthet Dent 2006;95:437-43.

43. Lai X, Si W, Jiang D, Sun T, Shao L, Deng B. Effects of small-grit grinding and glazing on mechanical behaviors and ageing resistance of a supertranslucent dental zirconia. J Dent 2017;66:23-31.

44. Sulaiman TA, Abdulmajeed AA, Donovan TE, Vallittu PK, Närhi TO, Lassila LV. The effect of staining and vacuum sintering on optical and mechanical properties of partially and fully stabilized monolithic zirconia. Dent Mater J 2015;34:605-10. 


\section{Translucent zirconia의 layer 간 비교 및 추가적인 소성이 굽힘강도, 투과도에 미치는 영향}

김형준 대학원생, 신수연* 교수

단국대학교 치과대학 치과보철학교실

목적: $5 \mathrm{Y}-\mathrm{ZP}$ 의 세가지 층 간 굽힘강도, 투과도를 비교하고 추가적인 소성이 미치는 영향을 연구하고자 하였다.

연구 재료 및 방법: 소결한 지르코니아 블록을 세가지 층에 따라 분리한 후 원형 디스크 시편을 제작하였다. 시편의 직경 은 $15.0 \mathrm{~mm}$ 이며, 2축굽힘강도와 투과도를 측정하기 위한 시편의 두께는 각각 $1.2 \mathrm{~mm}$ 와 $1.0 \mathrm{~mm}$ 이다. 시편들을 추가적 인 소성 횟수 $\left(0,1,3\right.$ 번)에 따라 세 군으로 분류한 후 추가적인 소성은 $900^{\circ} \mathrm{C}$ 이하의 온도에서 퍼니스를 사용하여 소성 횟 수에 따라 시행하였다. 만능재료시험기와 자외선-가시광선 분광광도계를 사용하여 2축굽힘강도와 투과도를 측정하였 다. 상의 변화를 관찰하기 위해 X선 회절 분석을 시행하였다. 측정값은 One-way ANOVA, Tukey HSD test를 통하여 분 석하였다 $(\alpha=0.05)$.

결과: 층 간 2축굽힘강도는 유의한 차이가 없었지만 $(P>0.05)$ 투과도는 유의한 차이가 있었다 $(P<0.05)$. 절단 및 전이 층은 1 번의 추가적인 소성 후 굽힘강도가 유의하게 감소하였으며, 3 번의 추가적인 소성 후에는 모든 층의 굽힘강도가 소 성 전과 비교하여 유의하게 감소하였다. 몸체 층을 제외한 나머지 층들은 추가적인 소성 후에 투과도가 유의하게 감소하 였다. 모든 그룹의 X선 회절 분석 결과는 유사하였다.

결론: $5 \mathrm{Y}-\mathrm{ZP}$ 의 세 층은 투과도의 차이만 존재하였다. 추가적인 소성은 각 층의 굽힘강도와 투과도에 다른 영향을 미쳤 으나 상전이는 발견되지 않았다.

(구강회복응용과학지 2021;37(3):111-22)

주요어: 단일 구조 지르코니아; 입방정계; 굽힘강도; 투과도; 5Y-ZP

*교신저자: 신수연

(31116) 충남 천안시 동남구 단대로 119 단국대학교 치과대학 치과보철학교실

Tel: 041-550-0256 | Fax: 041-550-1975 | E-mail: syshin@dankook. ac. kr

접수일: 2021년 6월 21일 | 수정일: 2021년 7월 13일 | 채택일: 2021년 7월 20일 